・论坛・

\title{
国家公园规划制度功能定位与空间属性
}

\author{
唐小平*
}

(国家林业和草原局调查规划设计院/国家公园监测评估研究中心, 北京 100714)

\begin{abstract}
摘要: 我国将构建统一的国土空间规划体系, 整体谋划国土空间开发保护格局, 强化对各类专项规划的指导约束, 这必将对国家公园保护制度产生重大影响。本文分析了国土空间规划视角下国家公园规划制度的定位，阐述了国 家公园规划承载空间规划与发展规划两大体系的基本属性，应在国土空间规划体系中具有优先权和前置权; 重点 分析了各国家公园总体规划在国家规划体系中的功能与属性特征，作为空间规划应承接好上位空间规划对国家公 园的控制指标和管控要求，作为建设规划应承接好上位或同域国民经济发展规划等对国家公园的目标任务要求, 作为管理规划要明确国家公园顺畅运行的要求。国家公园应在分区规划、控制性详细规划等专项规划方面寻求创 新, 探索国家公园用途管制的实现模式。
\end{abstract}

关键词: 国家公园; 自然保护地; 国土空间规划; 总体规划; 用途管制

\section{Functional orientation and spatial attribute analysis of the National Park Planning System of China}

\begin{abstract}
Xiaoping Tang*
Academy of Forest Inventory and Planning/National Park Monitoring and Evaluation Research Center, State Forestry and Grassland Administration, Beijing 100714
\end{abstract}

\begin{abstract}
China will construct a unified land and space planning system, plan the overall pattern of land and space development and protection, and increase the amount of guidance and restraint on various spatial plans. These changes will have a significant impact on the national park protection system. Here, we analyze the the national park planning system from a land and space planning perspective. The national park planning system includes attributes for space planning and development planning. Therefore, there should be a priority placed on the land space and planning systems. In addition, there should be a focus on the analysis of the function of the overall national park master plan for the space planning system. As a spatial plan, it is necessary to implement the control indicators and management requirements of a higher-level spatial plan for national parks. As a construction plan, it is important to undertake the higher-level or national economic development planning requirements for the target tasks in national parks. Finally, as a management plan, there must be clear requirments for smoothly running the national parks. National parks should seek innovation in special planning such as zone planning, regulatory detailed planning, and exploring the implementation mode for national park use control.
\end{abstract}

Key words: national park; nature protected area; land and space planning; master plan; use control

2019年5月，中共中央、国务院印发了《关于建 立国土空间规划体系并监督实施的若干意见》(以下 简称《若干意见》), 将目前的主体功能区规划、土 地利用规划、城乡规划等空间规划融合为统一的国 土空间规划, 实现多规合一, 强化国土空间规划对
各专项规划的指导约束作用。国家公园作为最重 要、保护最严格的自然生态空间, 是新时代整体谋 划国土空间开发保护格局的焦点, 构建并实施国土 空间规划体系必将对国家公园规划制度起到积极 作用并形成重大影响。在国土空间规划视角下, 研

收稿日期: 2020-02-13; 接受日期: 2020-05-19

基金项目: 中国科学院战略性先导科技专项(A 类)美丽中国生态文建设科技工程的全国自然保护地状况调查与保护成效专题(2019K-2)

* 通讯作者 Author for correspondence. E-mail: tang8043@126.com 
究确立国家公园规划制度构成及内涵，理顺国家公 园总体规划与同域空间规划、发展规划的关系, 明 确国家公园总体规划功能属性, 对于加快构建国家 公园保护制度, 实现我国自然保护地治理体系和治 理能力现代化具有重要意义。

\section{国家公园规划制度}

\section{1 构建国家公园规划制度}

国家公园规划制度就是确保国家公园建设管 理策略能够科学落图、落地、实施的一系列规章、 条例、规则、办法等行为规范的集合, 从宏观到微 观、从长远到近期构建统一、分层的国家公园规划 体系是主线。目前, 我国正在构建以发展规划、总 体规划、专项规划(管理计划)和年度计划组成的两 个序列、四个层级的国家公园规划体系(唐小平等, 2019)。发展规划在横向上承接国家的社会经济发展 规划、国土空间规划、自然保护地体系规划等, 向 下指导各国家公园建设管理。在实体国家公园层面, 总体规划作为每个国家公园的纲领性文件应涉及 所有规划期需要开展的建设管理项目、活动或要求, 但这应该是纲领性的、原则性的，而不是执行或操 作层面的，还应通过配套编制系列专项规划、管理 计划、实施方案等落地性的规划设计文件来实现。

目前开展的三江源、东北虎豹等10个国家公园 试点都是采用 “总体规划+专项规划+项目设计”的 模式推进，常见的专项规划有生态修复、基础设施 建设、移民搬迁等, 但在国土空间规划视角下, 还 需要在分区控制性规划和政策细化方面寻求突破。 专项规划应针对特殊问题制定一系列更加详细的 政策措施，如资源管理规划的目标是明晰管理行为 的责任与程序, 以解决资源利用方式、强度和控制 性指标等问题; 服务规划是游客活动管理过程的一 部分, 在符合资源与遗产保护规定的同时, 通过市 场定位综合考虑公园游客的需求、期望和满意度来 制定。服务规划要确定国家公园游览项目的方向和 优先顺序, 将管理规划中概念性的内容转化为提供 给公众的切实的服务以及相应的执行策略等(许学 工, 2001; 马之野等, 2019)。

\section{2 国家公园总体规划性质定位}

总体规划是国家公园规划制度的重要一环, 目
前专家学者对其性质定位仍然存在不同的理解。 《若干意见》明确了包含国家公园在内的自然保护 地规划作为国土空间专项规划的定位，是“为体现 特定功能，对特定区域的空间开发保护利用作出的 专门安排”。但按照《建立国家公园体制总体方案》 (简称《总体方案》), 国家公园总体规划的性质可理 解为保护管理规划, 是决定每个国家公园在未来较 长时间内发展方向的综合性规划，它包含了国家公 园的典型特征和保护愿景。国家公园总体规划不仅 会划出边界, 还会划出利益结构, 指明发展方式, 提出国家公园的基本原则、功能定位、管理目标、 范围分区。既从空间和职能上明确了利益结构, 也 明确了相关各方在管理国家公园和处理与国家公 园管理机构关系时的规则(苏杨, 2018)。国家公园总 体规划主要用于国家公园资源保护与发展建设指 导，是公园发展建设过程中的主要规划指导文件， 关键是协调分区保护强度与发展之间的辩证关系; 协调各项建设项目与土地利用之间的关系; 布局与 协调基础与服务类专项规划发展规模与容量之间 的关系; 研究近期项目的发展规模、用地规模及投 资估算等(严国泰和沈豪, 2015)。

从国际经验来看, 美国是设立国家公园最早并 采用总体规划指导国家公园建设管理最早的国家。 1932年，美国国家公园管理局正式采用总体规划 (master plan, MP)一词。1975年开始采用总体管理规 划(general management plans, GMP)替代总体规划 (杨锐, 2003), 更加强调资源保护、环境监测、游客 影响管理和公众参与等方面的内容及要求。在美国 国家公园规划体系中, 总体管理规划是统领全局的 纲领性文件，是制定国家公园管理决策的基础。20 世纪90年代至今的决策体系阶段是美国国家公园 规划的又一次变革, 强调不同层次的规划解决不同 的问题，规划成果包括: 总体管理规划、项目规划、 战略规划、实施规划、年度执行计划等。2016年开 始，美国国家公园管理局全面推行为每个国家公园 编制基础性文件(foundation document, FD)的新规 划体系，以取代当前强调层次性的既有规划体系 (扬子江等，2015)。FD作为每个国家公园的纲领文 件，在确立国家公园的目的、意义、主题和目标以 及指导后续规划的启动与开展方面取代了总体管 理规划(GMP)的指导性地位, 对于总体管理规划中 
涉及的相对具体的环境影响评估、自然人文资源保 护、游客体验规划等内容, 则在能落实到场地的具 体规划中按需开展, 不作为基础性文件中的章节重 复出现(杨伊萌, 2016)。

借鉴国际经验，我国国家公园总体规划将越来 越趋于综合性、基础性和层次性, 是国家公园范围 内最基础的“多规合一”成果，是国家公园空间管理 和发展建设的纲领性文件, 区域内其他各类规划应 遵从并根据总体规划进行修编和调整，同时具有空 间属性、建设属性和管理属性(表1)。

从表1看, 总体规划一方面要承接上位空间规 划对国家公园的控制指标和管控要求，明确国家公 园这个特定区域的特定保护利用安排, 作为明确国 家公园四至边界、管控分区及用途管制的依据; 另 一方面, 我国国家公园区别于美国、加拿大等国家, 尚处于开始设立和急需建设时期, 还要承接上位或 同域国民经济和社会发展规划等对国家公园目标 任务要求, 作为指导国家公园发展和确定建设项目 的依据, 以及确定和考核生态资源保护管理目标、 计划与任务的依据; 同时, 还要明确保障国家公园 顺畅运行的要求, 作为确定国家公园治理体系、管 理计划、人员编制、投资和财政经费的依据。因此, 应强化规划的权威性, 经批准的国家公园规划是国 家公园保护、利用和管理的纲领性文件，任何机构 和个人不得违反国家公园规划审批、开展各类建 设、生产经营活动。

\section{国家公园规划制度在国家规划体系中的定保}

\section{1 国土空间规划视角下的国家公园规划制度}

《若干意见》对自然保护地在国土空间规划体 系中的定位论述清晰，基本有三个含义：(1)我国国 土空间规划体系包括总体规划、详细规划和相关专 项规划三类，自然保护地规划属于专项规划; (2)国 家、省、市县编制国土空间总体规划，各地结合实 际编制乡镇国土空间规划，自然保护地专项规划由 所在区域或上一级自然资源主管部门牵头组织编 制; (3)国土空间总体规划是相关专项规划的基础, 相关专项规划要与详细规划做好衔接。但国家公园 如何嵌入国土空间规划体系中，如何理顺国家公园 规划与同域空间规划的关系还需要在实践中进一 步明晰。

国土空间是自然资源与生态系统的载体，国土 空间规划是对一定区域国土空间开发保护在空间 和时间上作出的安排。欧洲理事会(The European Council)认为“区域空间规划是经济、社会、文化和 生态政策在空间上的体现，目标是为了实现区域的 平衡发展以及空间安排，是一种跨领域的、综合性 的规划方法”。空间规划的职能不再局限于用地空 间的安排，而被视为整合各类政策的重要空间手段 (许景权等, 2017)。按照国家现行技术标准及指南的 相关要求，首先应体现国家意志和国家发展规划的 战略性，自上而下编制各级国土空间规划; 二是在

表1 国家公园总体规划的属性及规划要点

Table 1 Attributes and planning points of the National Park Master Plan

\begin{tabular}{|c|c|}
\hline 属性 Attribute & 规划要点 Planning points \\
\hline $\begin{array}{l}\text { 空间属性 } \\
\text { Spatial attribute }\end{array}$ & $\begin{array}{l}\text { (1)统筹考虑自然生态系统完整性和周边经济社会发展的需要, 合理划定国家公园边界; (2)划定核心保护区与一般控制 } \\
\text { 区边界; (3)连接公园内外的生态廊道; (4)明确差别化管控措施, 实行用途管制。 } \\
\text { (1) Considering the integrity of the natural ecosystem and the needs of the circumjacent area economic and social development } \\
\text { as a whole, the boundary of the national park should be delimited reasonably; (2) Delimiting the boundary between the core } \\
\text { protection areas and the general control areas; (3) Connecting the ecological corridor inside and outside the park; (4) Defining } \\
\text { differentiated control measures and implement use control. }\end{array}$ \\
\hline $\begin{array}{l}\text { 建设属性 } \\
\text { Construction attribute }\end{array}$ & $\begin{array}{l}\text { (1)确定保护、教育、科研、游憩、社区发展等功能的重点项目; (2)基础设施及建设安排; (3)国家公园保护管理能力建 } \\
\text { 设。 } \\
\text { (1) Determining the key projects of protection, education, scientific research, recreation, community development and other } \\
\text { functions; (2) Infrastructure and construction arrangement; (3) Capacity building of national park protection and management. }\end{array}$ \\
\hline $\begin{array}{l}\text { 管理属性 } \\
\text { Management attribute }\end{array}$ & $\begin{array}{l}\text { (1)明确国家公园及各区域管理目标; (2)明确公园管理体系(管护站点、管理机构与人员编制); (3)明晰自然资源资产产 } \\
\text { 权, 落实土地权属, 明确自然资源资产管理体制; (4)明确自然保护地资源利用管理要求与模式; (5)构建自然保护地运 } \\
\text { 行机制(协调、监督、特许经营等)。 } \\
\text { (1) Defining the management objectives of national parks and regions; (2) Construction of management system (management } \\
\text { and protection site, management organization and staffing); (3) Clarifying the property rights of natural resources assets, } \\
\text { implementing the ownership of land, and clarify the management system of natural resources assets; (4) Making clear the } \\
\text { requirements and models of resource utilization and management; (5) Construction of operation mechanism (coordination, } \\
\text { supervision, franchise, etc.). }\end{array}$ \\
\hline
\end{tabular}


资源环境承载能力评价和国土空间开发适宜性评 价的基础上, 科学有序统筹布局生态、农业、城镇 等功能空间, “双评价”是空间规划编制的科学基础。 这种编制思路充分体现了空间规划的战略性、科学 性, 但对于国家公园空间布局和总体规划会形成几 个关键制约: (1) “双评价”的出发点更多是基于国土 空间的开发利用而不是自然保护价值, 目前相关技 术指南选择的指标还是侧重于资源环境要素、生态 功能、生态敏感性等方面, 而国家公园承担的责任 是要以保护具有国家代表性的自然生态系统为主 要目的, 把我国自然生态系统中最重要、自然景观 最独特、自然遗产最精华、生物多样性最富集的区 域采取最严格的措施保护起来, 使当代和后代能够 享受大自然带来的生态福祉, 评价的聚焦点应该是 自然生态系统、自然景观、自然遗产和生物多样性 的重要程度。目前, 资源环境承载力评价过程中的 生态要素承载力判断缺乏逻辑关系(岳文泽等, 2019), “双评价”技术路线和方法还不能很好地解决 自然保护价值的评估问题。(2)国土空间规划实行的 是层层传导的五级垂直控制方式，自上而下层层控 制下一级规划，但国家级总体规划侧重于战略性， 省级总体规划侧重于协调性, 只有市县级乃至乡镇 级才能细化落实。而国家公园事关国家事权, 规划 权更是中央事权, 必须改变以往地方申报、地方规 划的传统做法, 打破行政界线, 按照生态系统完整 性统筹规划, 如果在低层级受制于市县甚至乡镇空 间规划、没有优先权, 则难以完整地嵌入国土空间 规划体系。(3)我国将构建以国家公园为主体的自然 保护地体系, 这种主体地位不是简单的面积最大, 而是所处的生态区位最为关键、代表性更强、保护 更加严格, 管理事权最高(唐小平等, 2017), 在低层 级衔接空间规划难以凸显国家公园的主体属性。

解决问题的最佳途径是将国家公园作为独立 单元, 参照一级行政区域编制总体规划, 赋予其空 间规划的地位和作用。早期实行空间规划制度的欧 洲大多数国家就是将国家公园独立规划, 如英国 1972年的《当地政府法》规定国家公园是独立的规 划单元(刘红纯, 2015)。实际上, 国家公园本来就是 一个边界清晰、跨行政区域的独立空间, 具有相当 大的体量和复杂性。即使按《若干意见》定位为国 土空间规划体系的专项规划, 也应该在层次定位方
面成为贯穿国家、省、市县三级国土空间规划体系 的专项规划, 在时序定位方面成为在国家和省域层 面前置的专项规划(赵智聪等, 2019)。同时，在各个 层面将国家公园规划制度与国土空间规划体系对 接, 在国家层面基于国家生态安全格局和生态地理 区划成果，独立开展自然生态空间保护价值评估， 将具有国家代表性的典型生态系统、自然遗迹、自 然景观和生物多样性富集区作为国家公园空间布 局的潜在区，优先纳入全国国土空间规划纲要; 在 省级层面, 基于更详细的自然生态本底和自然遗迹 调查摸底成果，结合自然保护地整合优化，对潜在 区进一步研究形成国家公园边界范围, 优先纳入省 级空间规划的生态空间; 在市县详细规划层面, 国 家公园总体规划承接省级空间规划对园区空间范 围提出的管控要求, 落实相关控制指标, 代替市县 级空间规划对国家公园内城镇区和农村居民点的 建设实施调控作用。在乡镇层面，考虑到国家公园 内城镇和农村社会等事务仍然归属于地方政府，也 可同步编制乡镇级空间规划与国家公园社区等分 区专项规划, 将空间管控指标、传统生产、集体建 设用地布局和分区准入标准等协调一致(图1)。

\section{2 国民经济社会发展规划视角下的国家公园规 划制度}

我国的国民经济和社会发展规划是中国特色 社会主义制度的重要组成部分, 其作用难以被其他 规划所替代，今后一段时期内发展规划与空间规划 两大体系可能是并行的。空间规划以发展规划为依 据，按照发展规划所确定的目标任务与相关要求, 合理确定国土空间的开发与保护格局; 发展规划的 制定要结合空间规划所确定的目标指标、管控边界 及空间要素配置等科学合理地确定经济社会发展 目标与任务(许景权等, 2017)。

国家公园规划制度不应只考虑空间规划要素, 也要明确建设发展任务。因此, 国家公园发展规划 必须全方位纳入国家社会经济发展规划体系，将发 展目标、空间布局、阶段任务和重点项目在国家层 面予以明确。同时，国家编制并颁发实施的非空间 类专项规划明确的目标、任务、措施等也应纳入国 家公园规划范畴，如自然保护地发展规划、天然林 保护修复中长期规划、湿地保护修复规划、草原保 护修复规划、野生动植物保护利用规划等(图1)。 


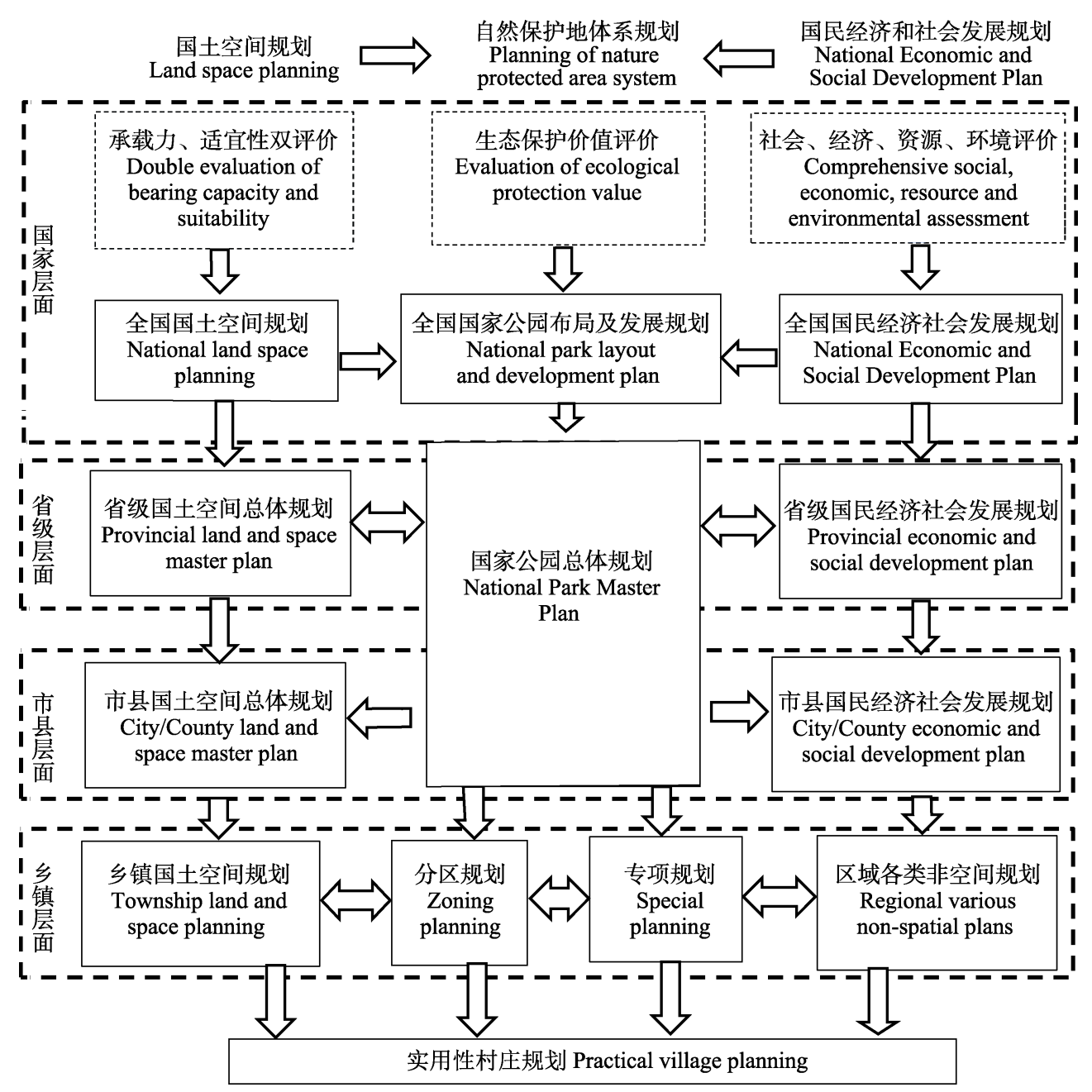

图1 国家公园规划、空间规划与发展规划关系图

Fig. 1 Relationship between national park planning, spatial planning and development planning

每个国家公园的总体规划，一方面应指导和控 制地方国民经济和社会发展规划的编制, 将国家公 园“生态保护第一、国家代表性、全民公益性”的核 心理念融入各级发展规划; 另一方面应将需要地方 政府承担的事权纳入同域行政区域国民经济与社 会发展规划, 主要包括社会发展、经济转型、公共 服务、防灾减灾等。国家公园同域还存在若干不同 类型、不同实施范围的非空间类规划, 由于各类规 划编制的逻辑思路和目标任务存在差异并且在空 间上形成重叠, 容易出现责任交叉、内容嵌套等问 题, 需要由国家公园管理机构与地方政府、相关部 门建立规划协同机制, 在国家公园总体规划中作好 融合或整合。对于生态保护、资源利用、公共服务 等内容, 原则上直接整合进入总体规划, 多规合一; 凡是国家或地方层面发展规划明确的重大工程项 目规划, 应评估与国家公园保护目标的协调性, 目
标基本一致或影响可控的工程项目原则上以融合 为主, 各规划之间统一目标、实施范围和任务要求, 但分列资金渠道、分设建设标准、分别管理要求。 如在三江源国家公园体制试验区，除颁发实施了 《三江源国家公园总体规划》外, 还实施了三江源 国家生态保护综合试验区总体方案、三江源生态保 护和建设二期工程规划、天然林保护实施方案、自 然保护区总体规划，以及地方各项规划、方案等， 前三项是国家公园编制总体规划的依据和融合对 象，而自然保护区总体规划等内容应整合纳入国家 公园总体规划。

\section{3 国家公园总体规划的空间属性}

\section{1 关于国家公园四至边界问题}

国家公园是边界清晰的生态保护红线区域, 界 定的对象为具有国家代表性的自然生态系统。如何 
划定国家公园的四至边界, 既是一个技术问题, 也 是一个政策问题, 是协调人地关系的重要手段, 可 以使宏观层面的国家公园概念细化为各利益相关 方认同的保护管理共识。《总体方案》要求: “确保 面积可以维持生态系统结构、过程、功能的完整 性……统筹考虑自然生态系统的完整性和周边经 济社会发展的需要, 合理划定单个国家公园范围”。 在具体界定国家公园边界范围时需要坚持几个基 本原则: (1)保持生态系统的完整性, 能够保护一个 或多个完整的自然生态系统; (2)考虑生态系统的原 真性, 尽量选择人为干扰少的自然区域, 呈现典型 自然风貌; (3)体现国家公园的公益性, 可以作为公 共财产、公有土地实现全民共享，个人、集体自然 资源资产也应具有实现统一管理、严格保护的可行 性；(4)有利于现有自然保护地的整合和国有林区、 垦区、牧区、渔场、苇场的经济转型; (5)统筹考虑 管理可行性，保持在自然村层级的边界完整，特别 是考虑历史遗留问题、民生问题、资金支持问题等， 做好与现有或规划工程项目、基础设施的衔接。

具体到不同区域、不同生态系统类型，国家公 园划界考虑因素会有所不同。如东北虎豹国家公园 划界重点考虑了东北虎 (Panthera tigris ssp. altaica)、东北豹(Panthera pardus orientalis)野生种 群从俄罗斯向我国内陆渗透、定居、繁殖和扩散的 完整路线需求, 选择最有希望定居繁衍的老爷岭种 群及其栖息地划建国家公园, 兼顾重点国有林区的 改革与发展转型，整合了已有的 12 个自然保护地， 国有土地占比超过 $92 \%$, 重点国有林区占 $83 \%$, 规 划区域实行中央政府垂直管理的基础非常好。祁连 山国家公园划界重点考虑了祁连山生态系统的完 整保护和水源涵养过程的完整性, 将祁连山地冰 川、雪山、高山草甸、湿地、源头汇水区、水源涵 养林、河流、生态草地等全部纳入了保护范围, 包 括祁连山东部森林、中部草原、西部荒漠、冰川、 湿地等典型生态系统。钱江源国家公园试点区因面 积较小、低海拔常绿阔叶林完整性不够, 在2019年 试点评估中提出了 “一园两区”的构想, 即在浙江丽 水凤阳山、百山祖的成片天然林分布区单独划建一 部分, 两块区域虽然不相连但都属于中亚热带东南 沿海山地生态系统的典型区域, 是华东植物区系起 源、演化的关键地区, 组合在一起可以呈现高-中低海拔常绿榈叶林的完整垂直带谱。
有学者从以“多规合一”为技术平台的国土空间 用途管制、以景观生态学为理念构建生命共同体的 双重视角，提出国家公园双层边界划定的构想，即 以刚性管控为主的内层边界和以弹性管理为主的 外层边界, 来适应生态系统的动态性、满足利益主 体诉求的多元性、体现规划管理的层次性，类似于 自然保护区外围的缓冲带，在我国也有一定的实践 意义(陈曦等, 2019)。

\section{2 关于国家公园管控与功能区划问题}

分区是实现空间用途管控的重要手段, 其作用 是界定园区每一块土地受保护的严格程度和主要 功能，在管理政策上平衡资源保护与利用的关系。 经过长期争论, 《建立以国家公园为主体的自然保 护地体系指导意见》明确了国家公园实行核心保护 区和一般控制区的两区管控，这种“二分法”模式改 变了现有自然保护地功能区划多样化的管理机制, 这是我国自然保护地管理理念首次从功能目标为 主线向管控要求为主线的转变, 实现了全方位对接 国土空间规划体系。如大熊猫国家公园四川片区的 两区划定模式, 将试点初期的严格保护区、生态保 育区、传统利用区、游咊展示区整合为核心保护区 和一般控制区，其中核心保护区占四川片区总面积 的77\% (图2)。这种基于管控要求的分区，一是便于 分类分区制定建设项目和资源利用清单，有效缓解 不同使用者或利益群体间的矛盾，同时最大可能地 保护原有自然环境不受侵害并且使严格而有差别 化的管控制度容易落地; 二是可以充分考虑到我国 人多地少的基本国情，管理机制更加灵活，有利于 协调自然保护与资源利用的关系，如在一般控制区 内扶持和规范原住居民从事环境友好型经营活动, 划定适当区域开展生态教育、自然体验、生态旅游 等活动和经营性的特许经营项目; 三是给解决历史 遗留问题留有余地，体现了实事求是、尊重历史的 思想(唐小平, 2019)。

功能区划是满足国家公园多目标管理需求的 一种有效管理路径，可以在管控分区的框架下进 行。与管控区比较, 功能区有几个典型特征：(1)因 已经存在严格意义的管控区划，基本没有承载用途 管制职能，对区划边界的要求不严格，可以只划出 一个大致界线而不需要划定落地的边界; (2)根据管 理目标而设, 一旦管理条件或管理需求发生变化, 可以随时改变或取消，也就是说功能区可以实行动 


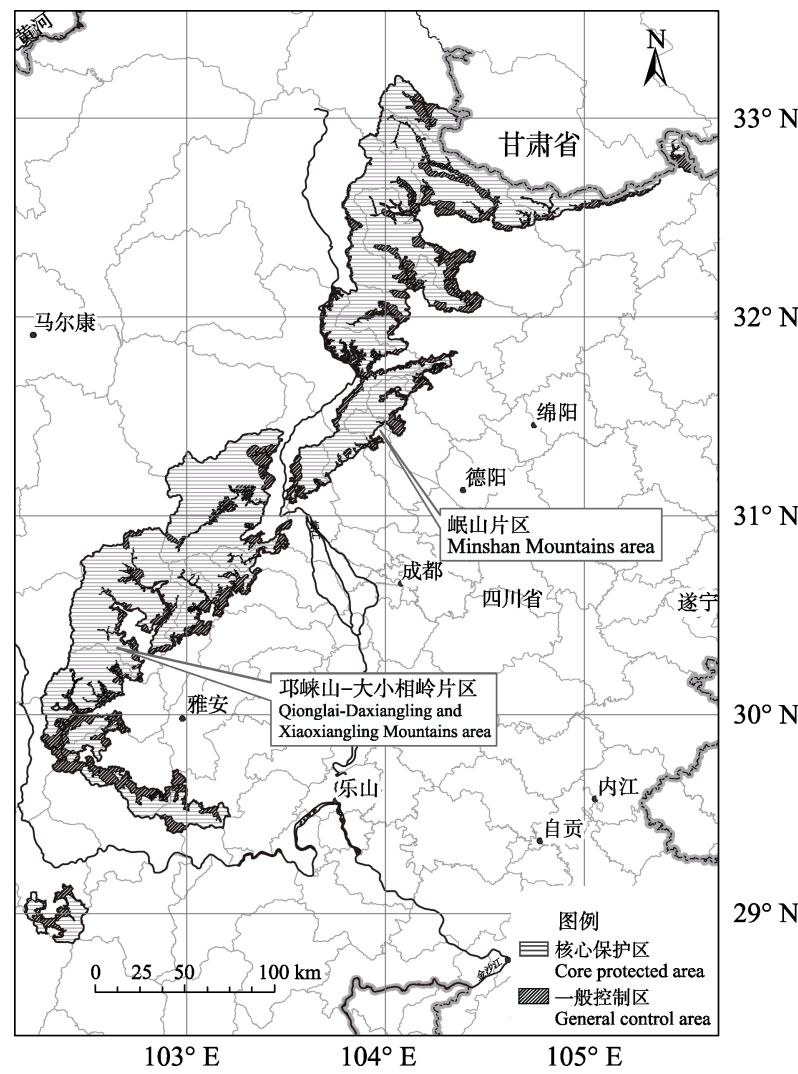

图2 大熊猫国家公园四川片区管控区划图

Fig. 2 Control zoning map of Sichuan area of giant panda National Park

态区划、动态管理; (3)管理措施主要是为了增强或 凸显国家公园某一方面的功能与作用, 但应遵从上 位管控区的要求; (4)可以根据管理需要设置线状、 带状、点状等功能区, 如穿越的道路、管线, 沿河 流设置的缓冲带, 以及连接同一功能斑块的生态廊 道等。

因此，国家公园功能区划的目的和管理可以多 样化: (1)实现不同的管理目标。国家公园主要的管 理目标包括保护、修复、科研、教育、游㓤、社区 发展等方面，管理目标不同就可以实行分区管理。 我国台湾的国家公园按照资源特性与土地利用形 态，划分为生态保护区、特别景观区、史迹保存区、 游憩区、一般管制区等区域，分区以点线面等不同 的空间形态存在于公园之内(张全洲和陈丹，2016); 俄罗斯国家公园一般划为核心区、特殊保护区、休 闲娱乐区、文化遗产保护区、经营管理区、自然资 源初级利用区，每个区域实现不同的管理目标(唐 小平等, 2018)。(2)实施精细化管理。日本自然公园 为更好地规范公园不同区域的使用强度, 按照生态
系统完整性和风光秀丽等级、人类影响程度、游客 使用的重要性等指标将土地划分为特别区域和普 通区域，其中特别区域是国立公园中最核心的保护 区，实施最严格的保护控制措施，特别区域又细分 为特别保护区及一、二、三类特别区域(赵人镜等, 2018)。(3)实施不同的经营利用强度。南非国家公 园按照野生动物及栖息地保护要求针对访客密度 划分为偏远核心区、偏远区、安静区、低强度休闲 利用区、高强度休闲区，建立了一个国家公园内及 周边连贯整体的的空间框架，来指导和协调生物多 样性保护、旅游和游客体验活动，降低这些活动之 间的冲突。(4)明确不同的管理责任。德国的《森林 法》规定森林所有者无权拒绝游人入林，即使是私 有林，人们也可以随意进入。一般在国家公园内专 门划出旅游休闲区域和进入系统，访客在区内活动 时由国家公园管理机构提供安全保障，但超出区域 的活动则不保障人身安全。

\section{3 关于国家公园分区规划问题}

分区规划是总体规划的细化，也是空间规划的 新趋势。国家公园通过分区规划可以明确特定管控 区域或功能区的边界和保护利益规定，约束或对接 同域空间规划。国家公园应重点在两个区域做好与 空间规划的对接：一是乡镇及村庄集中区，即“社 区空间”。《若干意见》提出: “各地结合实际编制乡 镇国土空间规划”; “在城镇开发边界外的乡村地区, 以一个或几个行政村为单元，由乡镇政府组织编制 “多规合一”的实用性村庄规划，作为详细规划”。国 家公园范围内、天窗或边界上都有较大规模的城 镇、社区居民点或林场(牧场、渔场)场址，人地情况 较为复杂, 体现在生活、生产、生态空间关系上的 矛盾十分集中。例如传统农牧业生产活动与物种保 育的关系、社区自主经营活动与访客管理的关系等, 需要通过分区编制详细规划确定乡村建设边界、传 统利用政策等，并对接当地乡镇空间规划或村庄规 划。二是国家公园的入口或门户城镇, 即“门户空 间”，虽然不在国家公园范围内，但其建设发展高 度依赖国家公园运营，随着游客人数的增加以及为 了追求更好生活质量而从大都市搬迁来的新家庭 人数的聚集, 门户城镇和国家公园在共享利益的同 时也面临着许多问题和挑战，需要国家公园主管机 构深度参与地方政府的空间规划，在全方位为国家 公园提供科研、教育、游㗹等公共服务的同时体现 
门户小镇特色(刘辉亮, 2016)。

\section{4 关于国家公园的用途管制问题}

不同于一般私有产权, 自然资源产权具有公益 性。为了实现某些自然资源的公益目的, 必须对自 然资源的用途予以一定的限制。

国土空间用途管制立足于自然资源的载体使 用监管，是自然资源监管体制的起始点和自然资源 生产监管的基础。构建空间规划体系是国土空间用 途管制的基本依据，对自然资源监管体制的完善具 有决定性的作用(林坚等, 2018)。国家公园作为自然 资源的重要载体，需要纳入国土空间用途管制制度， 按照《若干意见》的要求, “对以国家公园为主体的 自然保护地、重要海域和海岛、重要水源地、文物 等实行特殊保护制度”。目前，国家印发了《关于在 国土空间规划中统筹划定落实三条控制线的指导 意见》, 将国家公园全部纳入生态保护红线, 核心 保护区原则上禁止人为活动, 其他区域严格禁止开 发性、生产性建设活动, 在符合现行法律法规的前 提下, 除国家重大战略项目外, 仅允许对生态功能 不造成破坏的“八类”有限人为活动。因此, 国家公 园用途管制的特殊保护制度已经明确为“管控区+ 许可清单”的模式。但这个制度框架还是很难落地 的, 如“零星的原住民在不扩大现有建设用地和耕 地规模前提下, 修缮生产生活设施, 保留生活必需 的少量种植、放牧、捕捞、养殖”, 是否在一般控制 区都允许? 是相对集中的“不扩大”还是高度分散的 “不扩大”?

另外, 国家公园用途管控实质上是对自然资源 利用的限制, 应以自然资源资产产权管理为基础, 以空间资源的合理配置和有效利用为核心，协调各 类资源在空间上的衔接, 解决各类资源在空间上的 矛盾和冲突, 实现保护、利用、建设活动在空间分 布上的不重不漏、不矛盾、不冲突(韩爱惠, 2019)。 因此, 有必要借鉴目前风景名胜区“总体规划+控制 性详细规划+土地类型”的管控模式, 对国家公园在 “管控区”的框架下进一步细化分区，分区按照控制 性详规的要求编制分区规划, 细化到具体地类、资 源类型, 特别是要对接好园地、宅基地、公共设施 用地、建设用地等地类, 以及森林、草原、水体、 湿地、动物栖息地等资源, 形成国家公园“一张图”, 按照土地和资源属性进行用途管制。

\section{结语}

我国2020年基本完成了国家公园体制试点，进 入正式设立国家公园的新阶段。为确保“国家所有、 全民共享、时代传承”的根本宗旨在中国国家公园 建设管理过程中不走样, 为子孙后代传承珍贵的自 然资产, 就需要在起步之初加强顶层设计, 构建好 符合中国国情的国家公园保护制度。

国家公园规划体系是国家公园制度的重要组 成部分, 规划制度的设计不仅需要厘清内部逻辑关 系, 更重要的是落实好国家生态文明建设重大战略, 特别是对接好国土空间规划体系、国民经济社会发 展规划制度、国土空间用途管制制度、以国家公园 为主体的自然保护地等重大制度改革要求。但目前 空间规划路径还满足不了国家公园作为国家事权 的要求，建议将国家公园作为一级行政区单独编制 国土空间总体规划，或者在现有空间规划体系中赋 予国家公园规划优先权。

本文探讨了在国土空间规划和国民经济社会 发展规划视角下如何构建国家公园规划制度，如何 定位国家公园总体规划的功能作用，重点分析了国 家公园总体规划的空间属性。国家公园总体规划应 该承担空间规划、建设规划和管理规划的三重责任, 在分区规划、控制性详细规划、用途管制模式等方 面有所创新。但因篇幅所限没有涉及国家公园规划 审批、实施监管等问题，有待今后进一步讨论。

\section{参考文献}

Chen X, Tang B, Liang SB (2019) Delimitation idea and suggestion of national park boundary from double perspectives. Planners, 35(17), 17-22. (in Chinese) [陈䂀, 唐波，梁松斌 (2019) 国家公园双层边界划定思路与建 议. 规划师, 35(17), 17-22.]

Han AH (2019) Discussion on natural resources asset management in national parks. Forestry Resources Management, (1), 1-5. (in Chinese) [韩爱惠 (2019) 国家 公园自然资源资产管理探讨. 林业资源管理, (1), 1-5.]

Lin J, Wu YX, Wu JY, Liu SY (2018) Construction of the spatial planning system. City Planning Review, (5), 9-17. (in Chinese) [林坚, 吴宇翔, 吴佳雨, 刘诗毅 (2018) 论 空间规划体系的构建——兼析空间规划、国土空间用途 管制与自然资源监管的关系. 城市规划, (5), 9-17.]

Liu HC (2015) References of national park legal system in main countries. Chinese Landscape Architecture, (11), 
73-77. (in Chinese) [刘红纯 (2015) 世界主要国家国家公 园立法和管理启示. 中国园林, (11), 73-77.]

Liu HL (2016) Experience and inspiration from construction of United States national parks and gateway communities. China Engineering Science, 18(5), 100-108. (in Chinese) [刘辉亮 (2016) 美国国家公园与门户城镇的建设经验与 启示. 中国工程科学, 18(5), 100-108.]

Ma ZY, Yang R, Zhao ZC (2019a) Considerations on national park planning management mechanism under the territorial and spatial planning background. Design Community, (6), 16-19. (in Chinese) [马之野, 杨锐, 赵智聪 (2019a) 国土 空间规划背景下的国家公园规划管理机制思考. 住区, (6), 16-19.]

Ma ZY, Yang R, Zhao ZC (2019b) Study on spatial regulatory function of national park general management plan. Landscape Architecture, 26(4), 17-19. (in Chinese) [马之 野, 杨锐, 赵智聪 (2019b) 国家公园总体规划空间管控 作用研究. 风景园林, 26(4), 17-19.]

Su Y (2018) Planning, demarcation, zoning, how to divide interests? China Development Observation, (9), 42-47. (in Chinese) [苏杨 (2018) 规划、划界、分区, 利益如何划 分? 中国发展观察, (9), 42-47.]

Tang XP (2019) Historical changes in the field of natural protection in China. China Land, (8), 9-13. (in Chinese) [唐 小平 (2019) 中国自然保护领域的历史性变革. 中国土 地, (8), 9-13.]

Tang XP, Chen JZ, Han AH, Wang FK (2018) The management system and experiences of nature reserves in Russia. Forestry Resources Management, (4), 154-159. (in Chinese) [唐小平, 陈君帜, 韩爱惠, 王风昆 (2018) 俄罗 斯自然保护地管理体制及其借鉴. 林业资源管理, (4), 154-159.]

Tang XP, Luan XF (2017) Developing a nature protected area system composed mainly national parks. Forestry Resources Management, (6), 1-8. (in Chinese) [唐小平, 奕晓峰 (2017) 构建以国家公园为主体的自然保护地体系. 林业 资源管理, (6), 1-8.]

Tang XP, Zhang YY, Liang BK, Song TY, Chen JZ (2019) Construction of the Planning System of China's National Parks. Journal of Beijing Forestry University (Social Sciences), 18(1), 5-12. (in Chinese) [唐小平, 张云毅, 梁 兵宽, 宋天宇, 陈君帜 (2019) 中国国家公园规划体系构 建研究. 北京林业大学学报(社会科学版), 18(1), 5-12.]

Xu JQ, Shen C, Hu TX, Du S, Zhang XM (2017) General concept and main tasks of building spatial planning system in China. Planners, 33(2), 5-11. (in Chinese) [许景权, 沈 迟, 胡天新, 杜澍, 张晓明 (2017) 构建我国空间规划体 系的总体思路和主要任务. 规划师, 33(2), 5-11.]

$\mathrm{Xu}$ XG (2001) Enlightenment from planning of natural protected areas in Canada. Biodiversity Science, 9, 306-309. (in Chinese with English abstract) [许学工 (2001) 加拿大 自然保护区规划的启迪. 生物多样性, 9, 306-309.]

Yan GT, Shen H (2015) Study on planning system of national park series of China. Chinese Landscape Architecture, (2), 15-18. (in Chinese) [严国泰, 沈豪 (2015) 中国国家公园 系列规划体系研究. 中国园林, (2), 15-18.].

Yang R (2003) Comments on the national park planning system of USA. Chinese Landscape Architecture, (1), 44-47. (in Chinese) [杨锐 (2003) 美国国家公园规划体系述评. 中 国园林, (1), 44-47.]

Yang YM (2016) Inspiration from the new development trend of national park planning system in the United States. In: 60 Years of Planning: Achievements and Challenges_-Proceedings of 2016 China Urban Planning Annual Meeting, pp. 132-140. China Construction Industry Press, Shenyang. (in Chinese) [杨伊萌 (2016) 美国国家公园规划体系发展新 动向的启示. 规划60年: 成就与挑战—-2016中国城市 规划年会论文集，132-140页. 中国建筑工业出版社，沈 阳.]

Yang ZJ, Lin L, Wang YJ (2015) US national park management planning. Planners, 31(11), 135-138. (in Chinese) [杨子江, 林雷, 王雅金 (2015) 美国国家公园总 体管理规划的解读与启示, 规划师, 31(11), 135-138.]

Yue WZ, Wang TY (2019) Logical problems on the evaluation of resources and environment carrying capacity for territorial spatial planning. China Land Science, 33(3), 1-8. (in Chinese) [岳文泽, 王田雨 (2019) 资源环境承载力评 价与国土空间规划的逻辑问题. 中国土地研究, 33(3), 1-8.]

Zhang QZ, Chen D (2016) Research on zoning management of Taiwan regional national parks and its enlightenment on mainland natural reserve areas. China Forest Products Industry, (6), 59-62. (in Chinese) [张全洲, 陈丹 (2016) 台湾地区国家公园分区管理对大陆自然保护区的启示. 林产工业, (6), 59-62.]

Zhao RJ, Shang QQ, Li X (2018) Concepts, management mechanism and enlightenment of ecological planning for national park in Japan. Journal of Chinese Urban Forestry, 16(4), 71-74. (in Chinese) [赵人镜, 尚琴琴, 李雄 (2018) 日本国家公园的生态规划理念、管理体制及其借鉴. 中国 城市林业, 16(4), 71-74.]

Zhao ZC, Yang R (2019) On the positioning of protected area planning in national spatial planning. Chinese Landscape Architecture, 35(8), 5-11. (in Chinese) [赵智聪, 杨锐 (2019) 论国土空间规划中自然保护地规划之定位. 中国 园林, 35(8), 5-11.]

(责任编委：徐卫华 责任编辑：时意专) 